\title{
ANALISIS KINERJA PEGAWAI PADA PT. ASURANSI UMUM BUMIPUTERA MUDA 1967 CABANG BENGKULU
}

\author{
Tito Irwanto ${ }^{1}$ \\ E-mail : tito.irwanto22@gmail.com \\ Karona Cahya Susena ${ }^{2}$ \\ E-mail : karona.cs@unived.ac.id \\ Nurhalimah Tusadiyah ${ }^{3}$ \\ E-mail : nurhalimahtusyadiyah56@gmail.com \\ UNIVERSITAS DEHASEN BENGKULU
}

\begin{abstract}
The purpose of this study was to analyze the performance of employees at PT. General Insurance for Young Bumiputera 1967 Bengkulu Branch. This research is a type of survey research that takes a sample from a participant and uses questionnaires as a data collection and participation tool for analysis, explaining and explaining certain phenomena through field research activities. The sample in this study were all employees of PT. 1967 Bengkulu branch of General Insurance Bumiputera Muda who took 18 people with the sampling method used is total sampling or census. The analytical method used in this study is a qualitative descriptive analysis method that uses the average distribution.

The results of this study indicate that, the performance of PT. General Insurance for Young Bumiputera 1967 Bengkulu Branch has been very good with an average value of employee performance is 4.24. The average value of work quality is 4.49. The average value of the amount of work is 4.10. The average value of timeliness is 4.14. The average value of cooperation is 4.39. The average value of the cost resolution is 4.20. The average value of supervision is 4.17 .
\end{abstract}

Keywords: Quality of work, Quantity of work, Timeliness, Cooperation, Emphasis on costs, Supervision

\section{PENDAHULUAN}

Setiap perusahan atau instansi pasti menginginkan hasil maksimal dalam mencapai target perusahaan. Perusahaan yang dapat berjalan secara efektif dan efisien diperoleh dari pengelolaan sumber daya manusia, hal ini yang paling mempengaruhi kinerja perusahaan. Salah satu faktor yang mempengaruhi kinerja karyawan adalah tingkat pencapaian target perusahaan yang tinggi. Hal ini mengakibatkan karyawan harus meluangkan waktu di luar jam kerja untuk mendapatkan nasabah untuk mencapai target 
dan menyelesaikan pekerjaan tepat waktu. Menurut Mangkunegara (2013:67) kinerja merupakan hasil kerja karyawan dalam melaksanakan tugas dan tanggung jawab yang diukur menurut kualitas dan kuantitas, jadi kinerja karyawan memiliki peranan yang sangat penting dalam sukses atau tidaknya suatu perusahaan.

Pada dasarnya penilaian kinerja pegawai adalah proses penilaian hasil kerja yang akan digunakan oleh pihak manajemen untuk memberi informasi kepada para pegawai secara individual, tentang mutu hasil pekerjaanya dipandang sudut kepentingan perusahaan atau instansi. Dalam hal ini, seorang pegawai harus diberitahu tentang pekerjaanya, dalam arti baik, sedang atau kurang. Pegawai akan terdorong untuk berprilaku atau memperbaiki serta mengikia kinerja (prestasi) dibawah standar. Sumber daya manusia yang berbakat, berkualitas, bermotivasi tinggi dan mau bekerja sama dalam team akan menjadi kunci keberhasilan perusahaan atau instansi. Karena itu pimpinan harus dapat menetapkan sasaran kerja yang akan menghasilkan pegawai yang berkualitas tinggi, bermotivasi tinggi dan produktif.

PT. Asuransi Umum Bumiputera Muda 1967 Cabang Bengkulu atau disingkat BUMIDA adalah perusahaan yang bergerak di bidang perasuransian yang tentunya tanpa terkecuali harus memanfaatkan kemajuan teknologi informasi sebagai sarana pendukung kegiatan berbisnisnya. Oleh karena itu, untuk mencapai atau mewujudkan visi misi tersebut salah satunya adalah tentunya diperlukan juga sumber daya manusia yang kompetitif. Di mana salah satu indikator dari sumber daya manusia yang kompetitif adalah dengan melihat kinerjanya.

\section{TINJAUAN PUSTAKA}

\section{Kinerja}

Kinerja dalam bahasa inggris disebut juga dengan job performance atau actual performance, yanng merupakan tingkat keberhasilan pegawai dalam menyelesaikan pekerjaanya. Kinerja bukan merupakan karakteristik individu, seperti bakat, atau kemampuan, namun merupakan perwujudan dari bakat atau kemampuan itu sendiri. Kinerja adalah hasil kerja dan perilaku kerja yang telah dicapai dalam menyelesaikan tugas dan tanggung jawab yang diberikan dalam suatu priode tertentu. Kinerja merupakan suatu fungsi dari motivasi dan kemampuan. Untuk menyelesaikan tugas atau pekerjaan seseorang sepatutnya dimiliki derajat kesedian dan tingkat kemampuan tertentu. Prawirosentono (2010:2) menyatakan kinerja adalah hasil kerja yang dapat dicapai oleh seseorang atau kelompok orang dalam suatu organisasi sesuai dengan wewenang dan tanggung jawab masing-masing dalam rangka upaya mencapai tujuan organisasi bersangkutan tidak melanggar hukum dan sesuai dengan moral maupun etika.

\section{Penilain Kinerja}

Penilaian kerja pada dasarnya ada dua aspek yang dinilai yaitu proses (perilaku) dan output (keluaran), tergantung pada jenis pekerjaan dan fokus penilaian yang dilakukan. Pekerjaan yang sifatnya berulang dan keluarannya mudah diidentifikasi, maka penilaian biasanya difokuskan pada output, sedangkan pada pekerjaan yang hasilnya sulit diidentifikasi maka fokus penilaian ditunjukan pada aktifitas atau proses (Rahmawati, 2012:15). 
Menurut Veithzal Rivai dan Ella Jauvani (2013:551), mengemukakan suatu perusahaan melakukan penilaian kinerja didasarkan pada dua alasan pokok, yaitu: (1) manajer memerlukan evaluasi yang objektif terhadap kinerja karyawan pada masa lalu yang digunakan untuk membuat keputusan di bidang SDM di masa yang akan datang, dan (2) manajer memerlukan alat yang memungkinkan untuk membantu karyawannya memberbaiki kinerja, merencanakan pekerjaan, mengembangkan kemampuan dan keterampilan untuk perkembangan karier dan memperkuat kualitas hubungan antar manajer yang bersangkutan dengan karyawannya.

\section{Indikator Kinerja}

Indikator kinerja merupakan ukuran kuantitatif atau kualitatif yang menggambarkan tingkat pencapaian suatu sasaran atau tujuan yang telah ditetapkan. Menurut Lohman dalam Abdullah (2014:145) indikator kinerja adalah suatu variabel yang digunakan untuk mengekspresikan secara kuantitatif efektivitas dan efisien proses atau operasi dengan berpedoman pada target-target dan tujuan organisasi. Moeheriono (2012:108) mendefinisikan indikator kinerja adalah nilai atau karakteristik tertentu yang digunakan untuk mengukur ouput atau outcome sesuatu kegiatan serta sebagai alat ukur yang dipergunakan untuk menentukan derajat keberhasilan suatu organisasi dalam mencapai tujuannya.

Menurut Mangkunegara (2011:75) menyebutkan indikator dari kinerja adalah sebagai berikut.

1. Kualitas Kerja, seberapa baik seorang karyawan mengerjakan apa yang seharusnya dikerjakan.

2. Kualitas kerja, seberapa lama seseorang pegawai bekerja dalam satu harinya. Kuantitas kerja ini dapat dilihat dari kecepatan kerja setiap pegawai itu masingmasing.

3. Pelaksanaan Tugas, seberapa jauh karyawan mampu melakukan pekerjaanya dengan akurat atau tidak ada kesalahan.

4. Tanggung jawab, kesadaran akan kewajiban melakukan pekerjaan dengan akurat atau tidak ada kesalahan.

\section{METODE PENELITIAN}

Metode Analisis yang digunakan dalam menganalisis data dari setelah ditabulasi adalah metode analisis deskriptif kualitatif menggunakan distribusi rata-rata untuk mengukur kecenderungan persepsi pegawai terhadap kinerja pegawai PT. Asuransi Umum Bumiputera Muda 1967 Cabang Bengkulu, dapat dilihat rumasnya sebagi berikut:

$$
\begin{aligned}
& \text { Interval Kelas }=\frac{\text { skor tertinggi }- \text { skor terendah }}{\text { banyaknya bilangan }} \\
& \text { Maka diperoleh interval kelas }=\frac{5-1}{5}=0,80
\end{aligned}
$$

Dari skala interval tersebut, selanjutnya diinterpretasikan kedalam rata-rata jawaban responden dengan kriteria: 
Tabel. Interval Rata-rata Persepsi Responden

\begin{tabular}{|l|l|l|}
\hline NO & Interval (Range) & Keterangan \\
\hline 1 & $1.00-1.80$ & Sangat Tidak Baik \\
\hline 2 & $1.80-2.59$ & Tidak Baik \\
\hline 3 & $2.60-3.39$ & Cukup Baik \\
\hline 4 & $3.40-4.19$ & Baik \\
\hline 5 & $4.20-5.00$ & Sangat Baik \\
\hline \multicolumn{3}{|c|}{ Sumber: Sugiyono (2010: 150$)$}
\end{tabular}

\section{HASIL PENELITIAN DAN PEMBAHASAN \\ HASIL}

\section{Analisis Distribusi Rata-Rata Jawaban Responden}

Berdasarkan hasil penyebaran kuisioner kepada 18 pegawai PT. Asuransi Umum Bumiputera Muda 1967 Cabang Bengkulu, maka dapat diketahui bahwa kinerja pegawai PT. Asuransi Umum Bumiputera Muda 1967 Cabang Bengkulu sebagai berikut.

1. Persepsi Responden Terhadap Kualitas Kerja

Kualitas kerja terdiri dari empat item pertanyaan. Setiap item pertanyaan memiliki lima pilihan jawaban menggunakan skala likert berjenjang $1-5$. Skala tersebut menunjukan tanggapan responden mulai dari sangat tidak setuju hingga sangat setuju. Berikut ini disajikan persepsi responden terhadap kualitas kerja.

Tabel: Persepsi Responden Terhadap Kualitas Kerja

\begin{tabular}{|c|c|c|c|c|c|c|c|c|}
\hline \multirow[t]{2}{*}{ Pertanyaan } & \multicolumn{5}{|c|}{ Tanggapan Responden } & \multirow[t]{2}{*}{ Jumlah } & \multirow{2}{*}{$\begin{array}{l}\text { Rata } \\
\text {-rata }\end{array}$} & \multirow[t]{2}{*}{ Keterangan } \\
\hline & SS & $\mathrm{S}$ & $\mathrm{CS}$ & TS & STS & & & \\
\hline 1 & 7 & 11 & 0 & 0 & 0 & 79 & 4,38 & Sangat Baik \\
\hline 2 & 5 & 13 & 0 & 0 & 0 & 77 & 4,27 & Sangat Baik \\
\hline 3 & 12 & 5 & 1 & 0 & 0 & 83 & 4,61 & Sangat Baik \\
\hline 4 & 14 & 3 & 1 & 0 & 0 & 85 & 4,72 & Sangat Baik \\
\hline Jumlah & & & & & & 324 & & \\
\hline Rata-rats & & & & & & & 4,49 & Sangat Baik \\
\hline
\end{tabular}

Sumber: Kuesioner, 2019

Keterangan:
a. $1,00-1,80$ : Sangat tidak baik
b. $1,81-2,60$ : Tidak baik
c. $2,61-3,40$ : Cukup baik
d. 3,41-4,20: Baik
e. 4,21 - 5,00 : Sangat baik

Berdasarkan tabel diatas, persepsi responden terhadap indikator kualitas kerja, maka diketahui bahwa nilai rata-rata jawaban responden adalah 4,49 termasuk pada interval 4,21 - 5,00 dengan kriteria sangat baik. Hal ini menunjukan bahwa pegawai PT. Asuransi Umum Bumiputera Muda 1967 Cabang Bengkulu memiliki kualitas kerja yang baik dalam melaksanakan pekerjaan, dengan kualitas kerja yang dimiliki tersebut tentu saja pegawai akan dapat mencapai kinerja terbaiknya. 
2. Persepsi Responden Terhadap Kuantitas Kerja

Kuantitas kerja terdiri dari empat item pertanyaan. Setiap item pertanyaan memiliki lima pilihan jawaban menggunakan skala likert berjenjang $1-5$. Skala tersebut menunjukan tanggapan responden mulai dari sangat tidak setuju hingga sangat setuju. Berikut ini disajikan persepsi responden terhadap kuantitas kerja.

Tabel : Persepsi Responden Terhadap Kuantitas Kerja

\begin{tabular}{|c|c|c|c|c|c|c|c|c|}
\hline \multirow[t]{2}{*}{ Pertanyaan } & \multicolumn{5}{|c|}{ Tanggapan Responden } & \multirow[t]{2}{*}{ Jumlah } & \multirow{2}{*}{$\begin{array}{l}\text { Rata } \\
\text {-rata }\end{array}$} & \multirow[t]{2}{*}{ Keterangan } \\
\hline & SS & $\mathrm{S}$ & CS & TS & STS & & & \\
\hline 1 & 3 & 10 & 5 & 0 & 0 & 70 & 3,88 & Baik \\
\hline 2 & 5 & 5 & 8 & 0 & 0 & 69 & 3,83 & Baik \\
\hline 3 & 10 & 4 & 4 & 0 & 0 & 78 & 4,33 & Sangat Baik \\
\hline 4 & 9 & 7 & 2 & 0 & 0 & 79 & 4.38 & Sangat Baik \\
\hline Jumlah & & & & & & 296 & & \\
\hline Rata-rata & & & & & & & 4,10 & Baik \\
\hline
\end{tabular}

Sumber: Kuesioner, 2019

Keterangan:
a. $1,00-1,80$ : Sangat tidak baik
b. 1,81 - 2,60 : Tidak baik
c. 2,61-3,40 : Cukup baik
d. 3,41-4,20: Baik
e. $4,21-5,00$ : Sangat baik

Berdasarkan tabel diatas, persepsi responden terhadap indikator kuantitas kerja, maka diketahui bahwa nilai rata-rata jawaban responden adalah 4,10 termasuk pada interval 3,41 - 4,20 dengan kriteria baik. Hal ini menunjukan bahwa pegawai PT. Asuransi Umum Bumiputera Muda 1967 Cabang Bengkulu mampu bekerja mengukur efisiensi waktu dengan hasil kerjanya dengan sangat baik.

3. Persepsi Responden Terhadap Ketepatan Waktu

Ketepatan waktu terdiri dari empat item pertanyaan. Setiap item pertanyaan memiliki lima pilihan jawaban menggunakan skala likert berjenjang $1-5$. Skala tersebut menunjukan tanggapan responden mulai dari sangat tidak setuju hingga sangat setuju. Berikut ini disajikan persepsi responden terhadap ketepatan waktu.

Tabel : Persepsi Responden Terhadap Ketepatan Waktu

\begin{tabular}{|c|c|c|c|c|c|c|c|c|}
\hline \multirow[t]{2}{*}{ Pertanyaan } & \multicolumn{5}{|c|}{ Tanggapan Responden } & \multirow[t]{2}{*}{ Jumlah } & \multirow{2}{*}{$\begin{array}{l}\text { Rata } \\
\text {-rata }\end{array}$} & \multirow[t]{2}{*}{ Keterangan } \\
\hline & SS & $\mathrm{S}$ & $\mathrm{CS}$ & TS & STS & & & \\
\hline 1 & 7 & 5 & 6 & 0 & 0 & 73 & 4,05 & Baik \\
\hline 2 & 9 & 6 & 3 & 0 & 0 & 78 & 4,33 & Sangat baik \\
\hline 3 & 2 & 13 & 3 & 0 & 0 & 71 & 3,94 & Baik \\
\hline 4 & 7 & 9 & 2 & 0 & 0 & 77 & 4,27 & Sangat Baik \\
\hline Jumlah & & & & & & 299 & & \\
\hline Rata-rata & & & & & & & 4,12 & Baik \\
\hline
\end{tabular}

Sumber: Kuesioner, 2019 
Keterangan:
a. $1,00-1,80$ : Sangat tidak baik
b. $1,81-2,60$ : Tidak baik
c. 2,61-3,40: Cukup baik
d. 3,41-4,20: Baik
e. 4,21 - 5,00 : Sangat baik

Berdasarkan tabel diatas, persepsi responden terhadap indikator ketepatan waktu, sistem manajemen kinerja menyatakan, salah satu indikator dari kinerja adalah ketepatan waktu dalam penyelesaian pekerjaan (Dharma dalam Ruky, 2011:44). maka diketahui bahwa nilai rata-rata jawaban responden adalah 4,12 termasuk pada interval 3,41-4,20 dengan kriteria baik. Hal ini menunjukan bahwa pegawai PT. Asuransi Umum Bumiputera Muda 1967 Cabang Bengkulu tepat waktu dalam melaksanakan pekerjaanya terutama dalam menyusun laporan dan memberikan pelayanan kepada nasabah.

\section{Persepsi Responden Terhadap Kerja Sama}

Kerja sama terdiri dari empat item pertanyaan. Setiap item pertanyaan memiliki lima pilihan jawaban menggunakan skala likert berjenjang $1-5$. Skala tersebut menunjukan tanggapan responden mulai dari sangat tidak setuju hingga sangat setuju. Berikut ini disajikan persepsi responden terhadap kerja sama.

Tabel : Persepsi Responden Terhadap Kerja Sama

\begin{tabular}{|c|c|c|c|c|c|c|c|c|}
\hline \multirow[t]{2}{*}{ Pertanyaan } & \multicolumn{5}{|c|}{ Tanggapan Responden } & \multirow[t]{2}{*}{ Jumlah } & \multirow{2}{*}{$\begin{array}{l}\text { Rata } \\
\text {-rata }\end{array}$} & \multirow[t]{2}{*}{ Keterangan } \\
\hline & SS & $\mathrm{S}$ & $\mathrm{CS}$ & TS & STS & & & \\
\hline 1 & 8 & 9 & 1 & 0 & 0 & 73 & 4,38 & Sangat baik \\
\hline 2 & 11 & 7 & 0 & 0 & 0 & 83 & 4,61 & Sangat baik \\
\hline 3 & 7 & 10 & 1 & 0 & 0 & 78 & 4,33 & Sangat baik \\
\hline 4 & 7 & 9 & 2 & 0 & 0 & 77 & 4,27 & Sangat Baik \\
\hline Jumlah & & & & & & 317 & & \\
\hline Rata-rata & & & & & & & 4,39 & Sangat baik \\
\hline
\end{tabular}

Sumber: Kuesioner, 2019

Keterangan:
a. $1,00-1,80:$ Sangat tidak baik
b. $1,81-2,60:$ Tidak baik
c. 2,61-3,40: Cukup baik
d. $3,41-4,20$ : Baik
e. 4,21 - 5,00 : Sangat baik

Berdasarkan tabel diatas, persepsi responden terhadap indikator kerja sama, maka diketahui bahwa nilai rata-rata jawaban responden adalah 4,39 termasuk pada interval 4,21 - 5,00 dengan kriteria sangat baik. Hal ini menunjukan bahwa pegawai PT. Asuransi Umum Bumiputera Muda 1967 Cabang Bengkulu mampu bekerja sama dalam melaksanakan pekerjaanya baik kepada sesama rekan kerja maupun atasannya dan mengutamakan kepentingan kelompok dari pada kepentingan pribadi dalam bekerja. 
5. Persepsi Responden Terhadap Penekanan Biaya

Penekanan biaya terdiri dari empat item pertanyaan. Setiap item pertanyaan memiliki lima pilihan jawaban menggunakan skala likert berjenjang $1-5$. Skala tersebut menunjukan tanggapan responden mulai dari sangat tidak setuju hingga sangat setuju. Berikut ini disajikan persepsi responden terhadap penekanan biaya.

Tabel: Persepsi Responden Terhadap Penekanan Biaya

\begin{tabular}{|c|c|c|c|c|c|c|c|c|}
\hline \multirow[t]{2}{*}{ Pertanyaan } & \multicolumn{5}{|c|}{ Tanggapan Responden } & \multirow[t]{2}{*}{ Jumlah } & \multirow{2}{*}{$\begin{array}{l}\text { Rata } \\
\text {-rata }\end{array}$} & \multirow[t]{2}{*}{ Keterangan } \\
\hline & SS & $\mathrm{S}$ & $\mathrm{CS}$ & TS & STS & & & \\
\hline 1 & 9 & 8 & 1 & 0 & 0 & 80 & 4,44 & Sangat baik \\
\hline 2 & 3 & 11 & 4 & 0 & 0 & 71 & 3,94 & Baik \\
\hline 3 & 13 & 2 & 3 & 0 & 0 & 82 & 4,55 & Sangat baik \\
\hline 4 & 4 & 8 & 6 & 0 & 0 & 70 & 3,88 & Baik \\
\hline Jumlah & & & & & & 303 & & \\
\hline Rata-rata & & & & & & & 4,20 & Sangat baik \\
\hline
\end{tabular}

Sumber: Kuesioner, 2019

Keterangan:
a. $1,00-1,80$ : Sangat tidak baik
b. 1,81-2,60 : Tidak baik
c. 2,61 - 3,40: Cukup baik
d. 3,41-4,20 : Baik
e. 4,21 - 5,00 : Sangat baik

Berdasarkan tabel diatas, persepsi responden terhadap indikator penekanan biaya maka diketahui bahwa nilai rata-rata jawaban responden adalah 4,20 termasuk pada interval 4,20 - 5,00 dengan kriteria baik. Hal ini menunjukan bahwa pegawai PT. Asuransi Umum Bumiputera Muda 1967 Cabang Bengkulu mampu menganggarkan biaya sebelum aktivitas perusahaan dijalankan artinya dengan biaya yang sudah dianggarkan tersebut merupakan sebagai acuan agar tidak melebihi dari yang sudah dianggarkan.

\section{Persepsi Responden Terhadap Pengawasan}

Pengawasan terdiri dari empat item pertanyaan. Setiap item pertanyaan memiliki lima pilihan jawaban menggunakan skala likert berjenjang $1-5$. Skala tersebut menunjukan tanggapan responden mulai dari sangat tidak setuju hingga sangat setuju. Berikut ini disajikan persepsi responden terhadap pengawasan.

Tabel : Persepsi Responden Terhadap Pengawasan

\begin{tabular}{|c|c|c|c|c|c|c|c|c|}
\hline \multirow[t]{2}{*}{ Pertanyaan } & \multicolumn{5}{|c|}{ Tanggapan Responden } & \multirow[t]{2}{*}{ Jumlah } & \multirow{2}{*}{$\begin{array}{l}\text { Rata } \\
\text {-rata }\end{array}$} & \multirow[t]{2}{*}{ Keterangan } \\
\hline & SS & $\mathrm{S}$ & $\mathrm{CS}$ & TS & STS & & & \\
\hline 1 & 7 & 1 & 10 & 0 & 0 & 69 & 3,83 & Baik \\
\hline 2 & 9 & 1 & 8 & 0 & 0 & 73 & 4,05 & Baik \\
\hline 3 & 8 & 5 & 5 & 0 & 0 & 75 & 4,16 & Baik \\
\hline 4 & 13 & 4 & 1 & 0 & 0 & 84 & 4,66 & Sangat baik \\
\hline Jumlah & & & & & & 301 & & \\
\hline Rata-rata & & & & & & & 4,17 & Baik \\
\hline
\end{tabular}

Sumber: Kuesioner, 2019 
Keterangan:

a. $1,00-1,80:$ Sangat tidak baik

b. $1,81-2,60$ : Tidak baik

c. $2,61-3,40$ : Cukup baik

d. 3,41-4,20: Baik

e. 4,21 - 5,00 : Sangat baik

Berdasarkan tabel diatas, persepsi responden terhadap indikator pengawasan maka diketahui bahwa nilai rata-rata jawaban responden adalah 4,17 termasuk pada interval 3,41 - 4,20 dengan kriteria baik. Oleh karena itu, setiap aktivitas pekerjaan memerlukan pengawasan sehingga pegawai PT. Asuransi Umum Bumiputera Muda 1967 Cabang Bengkulu tidak melanggar aturan dari yang telah ditetapkan dengan adanya pengawasan maka setiap pekerjaan akan menghasilkan kinerja yang baik.

\section{PEMBAHASAN}

Upaya dalam mendorong pengembangan serta kemajuan instansi/ organisasi, pihak manajemen instansi/ organisasi perlu memperhatikan kinerja pegawainya karena peningkatan kinerja pegawai yang baik akan memberikan dampak positif dalam pencapaian tujuan/ organisasi tersebut. Berdasarkan persepsi responden terhadap indikator kualitas kerja, maka diketahui bahwa nilai rata-rata jawaban responden adalah 4,49 berada pada interval 4,20 - 5,00 yaitu dalam keadaan sangat baik, nilai rata-ta jawaban responden terhadap kuantitas kerja adalah 4,10 berada pada interval 3,40 4,19 yaitu dalam keadaan baik, nilai rata-rata jawaban responden terhadap ketepatan waktu adalah 4,12 berada pada interval $3,40-4,19$ yaitu dalam keadaan baik, nilai ratarata jawaban responden terhadap kerja sama adalah 4,39 berada pada interval 4,20 5,00 yaitu dalam keadaan sangat baik, nilai rata-rata jawaban responden terhadap penekanan biaya adalah 4,20 berada pada interval 4,20 - 5,00 yaitu dalam keadaan baik, dan nilai rata-rata jawaban responden terhadap pengawasan adalah 4,17 berada pada interval 3,40 - 4,19 yaitu dalam keadaan baik.

Sebagaimana dikemukakan oleh Mangkunegara (20011:74) yaitu hasil kerja secara kualitas dan kuantitas yang dicapai oleh seorang pegawai dalam melaksanakan tugasnya sesuai dengan tanggung jawab yang diberikan kepadanya. Oleh karena itu dapat dikatakan bahwa keberhasilan organisasi/ instansi dalam mencapai tujuan merupakan kontribusi dari hasil kerja pegawai dengan tingkat loyalitas dan kinerja yang tinggi. Dari hasil penelitian diatas diketahui bahwa seluruh indikator yang diajukan dalam penelitian ini telah dijalankan dengan baik dan benar oleh pegawai PT. Asuransi Umum Bumiputera Muda 1967 Cabang Bengkulu. Bagi PT. Asuransi Umum Bumiputera Muda 1967 Cabang Bengkulu keseluruhan indikator yang diajukan memang sangatlah penting untuk direalisasikan pada PT. Asuransi umum Bumiputera Muda 1967 Cabang Bengkulu, mengapa demikian karena kinerja pegawai yang baik adalah salah satu hal mutlak dan harus dilaksanakan, dimana hal tersebut merupakan kunci untuk menuju kesuksesan dalam mencapai tujuan dari organisasi atau instansi.

Dari hasil pernyataan responden yang telah dilakukan terhdap 18 orang responden, dalam hal ini pegawai PT. Asuransi Umum Bumiputera Muda 1967 Cabang Bengkulu 
maka seca umum kinerja pegawai sudah sangat baik, hal tersebut meliputi kualitas kerja, kuantitas kerja, ketepatan waktu, kerja sama, penekanan biaya,dan pengawasan.

Dari keseluruhan indikator maka dapat diketahui bahwa nilai rata-rata setiap indikator kinerja pegawai sebagai berikut :

Tabel Nilai rata-rata indikator kinerja pegawai.

\begin{tabular}{|c|c|l|l|}
\hline Pertanyaan & Indikator & ata-rata & Keterangan \\
\hline 1 & Kualitas kerja & 4,49 & Sangat baik \\
\hline 2 & Kuantitas kerja & 4,10 & Baik \\
\hline 3 & Ketepatan waktu & 4,12 & Baik \\
\hline 4 & Kerja sama & 4,39 & Sangat baik \\
\hline 5 & Penekanan biaya & 4,20 & Baik \\
\hline 6 & Pengawasan & 4,17 & Baik \\
\hline \multicolumn{2}{|l|}{ Rata-rata } & 4,24 & Sangat baik \\
\hline
\end{tabular}

Sumber : diolah, 2019

Berdasarkan tabel diatas, diketahui bahwa kinerja pegawai PT. Asuransi Umum Bumiputera Muda 1967 sudah sangat baik dengan nilai rata-rata persepsi responden terhadap seluruh indikator kinerja pegawai yaitu 4,24. Dari keseluruhan data yang telah dianalisis maka diketahui bahwa kinerja pegawai PT. Asuransi Umum Bumiputera Muda 1967 Cabang Bengkulu dalam keadaan sangat baik dan berjalan semestinya. Menurut Wahyudi dalam Kesuma (2011:82), salah satu aspek penilaian kualitas kerja adalah karyawan memahami secara jelas tentang "uraian tugas dan spesifikasinya" serta dapat dicapai berdasarkan standar yang berlaku atau yang disepakati, dimana karyawan harus bekerja sesuai fungsi tugas yang dibebankan kepadanya. Pegawai PT. Asuransi Umum Bumiputera Muda 1967 Cabang Bengkulu telah memiliki kualitas yang baik dalam melaksanakan pekerjaan, tentu saja pegawai akan dapat mencapai kinerja terbaiknya. Pegawai PT. Asuransi Umum Bumiputera Muda 1967 Cabang Bengkulu juga memiliki kuantitas kerja yang baik. Alwi (2010:55) menjelaskan bahwa, kuantitas kerja yang efektif berarti karyawan harus berupaya dengan sekuat tenaga dan memaksimalkan semua sumber daya yang ada untuk mencapai hasil kerja yang maksimum dan sesuai target.

Sistem manajemen kinerja menyatakan, salah satu indikator dari kinerja adalah ketepatan waktu dalam menyelesaikan pekerjaan (Dharma dalam Ruky, 2011:44). Pegawai PT. Asuransi Umum Bumiputera Muda 1967 Cabang Bengkulu sudah termasuk kreteria baik dalam indikator ketepatan waktu, yang berarti pegawai PT. Asuransi Umum Bumiputera Muda 1967 Cabang Bengkulu tepat waktu dalam melaksanakan pekerjaannya dan melayani nasabah. Pegawai PT. Asuransi Umum Bumiputera Muda 1967 Cabang Bengkulu memiliki kreteria sangat baik dalam kerja sama, hal ini berarti mampu bekerja sama dalam melaksanakan pekerjaan baik sesama rekan kerja maupun atasanya. Malayu dalam Umar (2010: 93), reseach sumber daya manusia, menyatakan bahwa adanya tiga jenis hubungan dalam organisasi yaitu: hubungan tunggal langsung (direct single relationships DRS), hubungan kelompok langsung (direct group relationships DGR), hubungan silang (cross relationships $C R$ ), serta total hubungan $(\mathrm{TH})$ yang merupakan total hubungan yang perlu dilakukan 
manajer jika semakin banyak akan semakin sulit dilakukan, begitu pula sebaliknya, semakin sedikit hubungan yang harus dilakukan akan semakin efektif.

Pada indikator penekanan biaya pegawai PT. Asuransi Umum Bumiputera Muda 1967 Cabang Bengkulu sudah termasuk kedalam kreteria baik, mengapa perlu ada penekanan biaya pada perusahaan PT. Asuransi Umum Bumiputera Muda 1967 Cabang Bengkulu, agar biaya yang dikeluarkan untuk aktivitas perusahaan tidak terjadi pemborosan. Kasmir (2016:208) penekanan biaya adalah biaya yang dikeluarkan untuk setiap aktivitas perusahaan sudah dianggarkan sebelum aktivitas dijalankan. Artinya dengan biaya yang sudah dianggarkan tersebut merupakan sebagai acuan agar tidak melebihi dari yang sudah dianggarkan.

Kualitas kerja, kuantitas kerja, ketepatan waktu, kerja sama, penekanan biaya saja tidaklah cukup untuk mencapai tujuan sebuah organisasi yang memiliki cakupan yang sangat luas seperti PT. Asuransi Umum Bumiputera Muda 1967 Cabang Bengkulu, maka perlu yang namanya pengawasan agar tidak ada hal lain yang diluar dugaan dari yang sudah direncanakan atau ditetapkan. Dengan melakukan pengawasan pegawai akan merasa lebih bertanggung jawab atas pekerjaanya dan jika terjadi penyimpangan akan memudahkan untuk melakukan evaluasi dan melakukan perbaikan secepatnya, artinya suatu pekerjaan tanpa dilakukan pengawasan akan mempengaruhi kinerja seseorang. Yang pasti tanpa pengawasan maka hasil kerja sudah dapat dipastikan akan memberikan hasil tidak baik bahkan lebih buruk yang diperkirakan.

\section{KESIMPULAN}

Berdasarkan hasil penelitian dan pembahasan, dapat diambil kesimpulan yakni kinerja PT. Asuransi Umum Bumiputera Muda 1967 Cabang Bengkulu sudah sangat baik dengan nilai rata-rata terhadap seluruh indikator kinerja pegawai yaitu 4,26. Kesimpulan akhir yang dapat ditarik dalam penelitian ini yaitu sebagai berikut:

1. Kinerja pegawai dengan indikator kualitas kerja nilai rata-rata 4,49 berada pada interval 4,20-5,20 (Sangat baik).

2. Kinerja pegawai dengan indikator kuantitas kerja nilai rata-rata 4,10 berada pada interval 3,40-4,19 (Baik).

3. Kinerja pegawai dengan indikator ketepatan waktu nilai rata-rata 4,14 berada pada interval 3,40-4,19 (Baik).

4. Kinerja pegawai dengan indikator kerja sama nilai rata-rata 4,39 berada pada interval 4,20 - 5,20 (Sangat baik).

5. Kinerja pegawai dengan indikator penekanan biaya nilai rata-rata 4,20 berada pada interval 4,20-5,20 (Baik).

6. Kinerja pegawai dengan indikator pengawasan nilai rata-rata 4,17 berada pada interval 3,40-4,17 (Baik).

\section{SARAN}

Penelitian mengenai analisis kinerja pegawai pada PT. Asuransi Umum Bumiputera Muda 1967 Cabang Bengkulu penulis menyarankan bahwa secara keseluruhan dari enam indikator kinerja pegawai sudah sangat baik, akan tetapi indikator tersebut dapat ditingkatkan lagi agar mendapatkan penilaian hasil yang baik terutama indikator 
ketepatan waktu, hendaknya lebih tegas menerapkan sanksi yang berlaku apabila ada pagawai yang tidak tepat waktu masuk jam kerja dan keluar izin dengan kepentingan pribadi, hal ini diharapkan dapat menjadikan pertimbangan/ masukan bagi pegawai dan pimpinan instansi terutama bagi pimpinan PT. Asuransi Umum Bumiputera Muda 1967 Cabang Bengkulu terus memperhatikan indikator-indikator yang menentukan peningkatan kinerja pegawai dalam bekerja sehingga pegawai dapat terus meningkatkan kinerjanya.

\section{DAFTAR PUSTAKA}

AA. Anwar Prabu Mangkunegara, 2015, Manajemen Sumber Daya Manusia Perusahaan, Remaja Rosdakarya, Bandung.

Abdullah, M. 2014. Manajemen dan Evaluasi Kinerja Karyawan. Yogyakarta : Penerbit Aswaja Pressindo.

Achmad, Tarmizi Ala' Rahmawati. 2012. Pengaruh kinerja Lingkungan Terhadap Financial Corporate performance dengan corporate social responsibility Disclosure Sebagai Variabel Intervening. Diponogoro journal of Accaunting. Vol. 1 No 2 Hal 1-15

Alwi. 2010. Manajemen Sumber Daya Manusia. Jakarta: Penerbit Erlangga

Dharma, S. 2011. Manajemen Kinerja. Jakarta: Pustaka Pelajar.

Hasibuan, Malayu. 2012. “Manajemen Sumber Daya Manusia”. Jakarta: PT Bumi Aksara

Kasmir. 2016. Manajemen Sumber Daya Manusia (Teori dan Praktik). Jakarta: PT Raja Grafindo Persada

Moeheriono. 2012. “Pengukuran Kinerja Berbasis Kompetensi”. Jakarta: Raja Grafindo Persada.

Rivai, V. dan Ella, J. 2013. Manajemen Sumber Daya Manusia untuk Perusahaan dari Teori ke Praktik. Jakarta: PT Raja Grafindo

Sugiyono. 2010. Metode Penelitian Pendidikan Pendekatan Kuantitatif, kualitatif, dan $R \& D$. Bandung: Alfabet

Veithzal Rivai, 2013, Manajemen Sumber Daya Manusia Untuk Perusahaan Dari Teori Ke Praktek, Rajagrafindo persada, Bandung.

Wahyudi, B. 2011. Manajemen Sumber Daya Manusia. Bandung: Sulita 